\title{
SPÓR LIBERAŁÓW Z KOMUNITARYSTAMI
}

Qpór liberałów z komunitarystami, obok sporu o postmodernizm, Onależy do najbardziej znaczących polemik we współczesnej filozofii polityki. Sam komunitaryzm pojawił się jako odpowiedź na dzieło Johna Rawlsa A Theory of Justice wydane w 1971 roku. Komunitaryzm można więc uznać w dużej mierze za nurt negatywny, oparty tylko na krytyce liberalizmu i na opozycji do niego. Sam jednak nie tworzy jednej i spójnej a także alternatywnej dla liberalizmu doktryny. W wymiarze pozytywnym za cechę wspólną dla całego nurtu uznać należy ideę afirmacji wspólnoty i zakorzenienia w niej jednostki ${ }^{1}$.

Krytyka komunitarystyczna w zasadniczej części nie odnosi się do liberalizmu jako takiego, lecz jego egalitarnej odmiany wywodzącej się z pracy Rawlsa oraz libertarianizmu Roberta Nozicka. Termin komunitaryzm związany jest etymologicznie z lacińskim communitas zbiorowość, wspólnota. Pojęcie to prawdopodobnie pojawiło się w 1841 r. i ukuł je założyciel Universal Communitarian Association, oznaczało ono członka wspólnoty wcielającej w życie idee komunistyczne i socjalistyczne. Swe współczesne znaczenie, czyli „to, co odnoszące się do wspólnoty", termin ten uzyskal na przełomie XIX i XX wieku². Chronologicznie rzecz biorąc, asumptem, który wywołal spór komunitarystów z liberałami jest wspomniana praca Johna Rawlsa. Natomiast za początek komunitaryzmu jako nurtu filozoficznego (a więc, logicznie rzecz biorąc, również za początek samego sporu) uznaje się odpowiedź Michaela Sandela na tezy Rawlsa zawarte w wydanej w 1982 r. książce Liberalism and the Limits of Justice ${ }^{3}$.

1 L. Dominiak, Komunitary rm, w: Encyklopedia „Biatych Plam”, Radom 2005, s. 187.

2 A. Etzioni, Introduction, w: The Essential Communitarian Reader, pod red. tegoż, Boston 1998, s. 9.

${ }^{3}$ F. Kampka, Komunitaryzm: kolejna ucieczka od wolności?, „Roczniki Nauk Społecznych”, 1996, t. 24, z. 1, s. 31. 
zaliczyć ${ }^{4}$ :

Do najważniejszych przedstawicieli komunitaryzmu można

1. Alasdaira Ch. MacIntyre'a, urodzonego w 1929 r. naturalizowanego w USA Szkota, filozofa amerykańskiego, profesora University of Notre Dame. Wykładał on w Oksfordzie, w Brandeis University, Boston University, Wellesley College, Vaderblit University, Duke University. W 1989 r. wykładał gościnnie w Whitney Humanities Center, Yale University. Można go zaliczyć do tzw. (A. Szahaj) komunitaryzmu nostalgicznego a jego najważniejszym dokonaniem jest próba odnowienia Arystotelesowskiej filozofii moralnej. Jego najważniejsze publikacje, to: Marxism: An Interpretation (1953), A Short History of Ethics: A History of Moral Philosophy from Homeric Age to The Twentieth Century (1966), Against the Self-Images of the Age: Essays in Ideology and Philosophy (1971), After Virtue: A Study in Moral Theory (1981), Whose Justice? Which Rationality? (1988), Three Rival Versions of Moral Enquiry (1990), Dependent Rational Animals (1999).

2. Charlesa Taylora, urodzonego w 1931 r. Kanadyjczyka, profesora nauk politycznych Uniwersytetu McGill w Montrealu, uważanego za jednego z najwybitniejszych współczesnych filozofów. W latach 1956-61 i 1976-81 wykładał on w Oksfordzie a w latach 1962-71 i od 1982 r. w Montrealu. Zaliczany jest do tzw. (A. Szahaj) komunitaryzmu republikańskiego. Jego najważniejsze dzieła, to: The Explanation of Behaviour (1964), Pattern of Politics (1970), Hegel (1975), Hegel and Modern Society (1979), Social Theory as Practice (1983), Philosophical Papers (1983), Human Agency and Language (1985), Philosophy and the Human Sciences (1985), Negative Freibeit (1988), Sources of the Self (1989), The Malaise of Modernity (1991), The Ethics of Authenticity (1992), Multiculturalism and "The Politics of Recognition" (1992).

3. Michaela J. Sandela, urodzonego w 1951 r. amerykańskiego filozofa i politologa, profesora Uniwersytetu Harvarda w Cambridge w Stanach Zjednoczonych, gdzie od 1980 r. wykłada filozofię polityki i historię myśli politycznej. Doktorat uzyskał on na Uniwersytecie Oksfordzkim. Jego wykład pt. Sprawiedliwość zgromadził ponad dziesięć tysięcy studentów, stając się jednym z najpopularniejszych kursów w historii Uniwersytetu Harvarda. W 1985 r. został laureatem nagrody HarvardRadcliffe Phi Beta Kappa Teaching Prize dla nauczycieli akademickich. Został członkiem powołanej przez prezydenta USA G. W. Busha rady zajmującej się etycznymi implikacjami technologii biomedycznych. Można go zaliczyć do tzw. (A. Szahaj) komunitaryzmu radykalnego. Jego najważniejsze dzieła, to: Liberalism and the Limits of Justice (1982), Liberalism

${ }^{4}$ Ł. Dominiak, Komunitaryzm, dz. cyt., s. 187. 
and Its Critics (red., 1984), Democracy's Discontent: America in Search of Public Philosophy (1996).

4. Michaela Walzera, urodzonego w 1937 filozofa prawa i polityki z Harvardu. Zaliczany jest on do tzw. (A. Szahaj) komunitaryzmu liberalnego. Jego najważniejsze dzieła, to: Political Action (1971), Regicide and Revolution (1974), Radical Principles (1977), Spheres of Justice: A Defence of Pluralism and Equality (1983), Interpretation and Social Criticism (1987), On Toleration (1997).

5. Roberta N. Bellaha, urodzonego w 1927 socjologa z Berkeley. Jego najważniejsze dzieła, to: The Broken Convenant: American Civil Religion in Time of Trial (1975), Beyond Belief: Essays on Religion in a Post-Traditional World (1979), Habits of the Heart: Individualism and Commitment in American Life (1985), The Good Society (1991).

Przywódcą ruchu komunitarystycznego jest Amitai Etzioni, z pochodzenia niemiecki Żyd, socjolog i socjoekonomista, były professor Harwardu, założyciel w 1988 r. oraz dyrektor Institute for Communitarian Policy Studies przy George Washington University w Waszyngtonie - Instytutu Komunitarystycznych Studiów Politycznych, wydającego kwartalnik „The Responsive Community: Rights and Responsibilities”. Jego najważniejsze dzieła, to: The Moral Dimension: Toward a New Economics (1993), The Spirit of Community: Rights, Responsibilities and the Communitarian Agenda (1993), The New Golden Rule: Community and Morality in a Democratic Society (1996), The Monochrome Society (2001), Next: The Road to the Good Society (2001).

Zarówno za liberalizmem jak i komunitaryzmem stoi całe bogactwo antenatów. Do poprzedników tego pierwszego zaliczyć należy Johna Locke'a, z myśli którego zaczerpnięto przekonanie, że ochrona życia, praw, własności obywateli jest rudymentarna rolą i argumentem na rzecz istnienia państwa. Immanuel Kant użyczył liberalizmowi swojego pojęcia autonomii, dzięki której jednostka może podejmować decyzje dotyczące inter alia: koncepcji życia, jego celu, wizji dobra i systemu wartości samodzielnie, bez przymusu i społecznego paternalizmu. Jednostka ograniczona jest jedynie swym wewnętrznym hamulcem, którym jest „rozum praktyczny”. Inspiracje czerpane z filozofii Johna Stuarta Milla poskutkowały zaliczeniem prawa do bezpieczeństwa socjalnego do katalogu wolności podstawowych. Za Millem również liberalizm dopuścił, iż jednostka nie zawsze postępuje w sposób racjonalny. Także idee komunitarystyczne są głęboko zakorzenione w tradycji filozoficznej. Jej linię da się wyznaczyć od Platona, Arystotelesa i Tomasza z Akwinu, potem zaś Georga Wilhelma Friedricha Hegla i jego opozycyjnej w stosunku do Kanta filozofii moralności i idei językowej 
heteronomii Johanna Gottfrieda Herdera. Ponadto komunitaryzm jest inspirowany republikanizmem Alexisa de Tocqueville'a i ideą woli powszechnej Jana Jakuba Rousseau. Na krytykę atomizmu społecznego i konsumeryzmu wyraźny wpływ wywarł Martin Heidegger, Carl Schmitt i Leo Strauss ${ }^{5}$. Ten ostatni sam był wielkim krytykiem zmian w świecie demokracji liberalnych, które jego zdaniem doprowadziły do kryzysu cywilizacji zachodniej.

By dokonać omówienia sporu liberałów z komunitarystami, należy najpierw przedstawić bliżej dzieło, które dla tego sporu stało się asumptem, czyli rawlsowską Teorie sprawiedliwości. Podstawową jej rolą było wskazanie reguł, w oparciu o które działać ma organizacja życia społecznego ${ }^{6}$. By dojść do tego, jak powinny wyglądać te zasady, odwołuje się do znanej uprzednio idei umowy społecznej. Umowa społeczna, którą opisuje Rawls, jest zawierana w „sytuacji pierwotnej”, czyli hipotetycznym stanie przedumownym. Jednak wizja autora odbiega od tych przedstawianych we wcześniejszych teoriach kontraktualnych, na przykład u Rousseau czy Hobbesa, gdyż nie jest ona po prostu teoria dotycząca przejścia od stanu przedpaństwowego do narodzin społeczeństwa. W sytuacji pierwotnej jednostki znajdują się za zasłoną niewiedzy, która ma być warunkiem sine qua non bezstronności wyboru. Jednostki te pozbawione są wszelkich różnicujących je akcydensów, a więc - cech charakterologicznych, pozycji społecznej i wizji dobra, tym samym nie maja żadnej cechy, która mogłaby interferować ich wybór. W takiej sytuacji będą one podejmowały decyzję tak, by jak najlepiej zabezpieczyć swoje interesy. Tylko tak sformułowane warunki pozwalaja, zdaniem Rawlsa, podjać jednostkom słuszny wybór zasad sprawiedliwości, a te "mają rządzić wyznaczaniem praw i obowiązków oraz kierować rozdziałem społecznych i ekonomicznych korzyści"7. Jednostki w sytuacji pierwotnej kieruja się tylko racjonalnością, której towarzyszy możliwość dokonywania wolnego wyboru. Są dwie zasady sprawiedliwości, do których dochodzą:

1. „Każda osoba winna mieć równe prawo do jak najszerszego całościowego systemu równych podstawowych wolności, dającego się pogodzić z podobnym systemem dla wszystkich.

2. Nierówności społeczne i ekonomiczne mają być tak ułożone, aby:

${ }^{5}$ R. Prostak, Rzeczo o sprawiedliwości, Kraków 2004, s. 26 i nast.

${ }^{6}$ A. Chmielewski, Społeczeństwo otwarte cayy wspólnota?, Wrocław 2001, s. 190.

7 J. Rawls, Teoria sprawiedliwości, Warszawa 1994, s. 87. 
a) były z jak największą korzyścią dla najbardziej upośledzonych, pozostając w zgodzie z zasada sprawiedliwego oszczędzania; i jednocześnie

b) aby były związane z dostępnością urzędów i stanowisk dla wszystkich w warunkach autentycznej równości szans"8.

Reguły sprawiedliwości zabezpieczone są dwiema dodatkowymi zasadami mającymi na celu ustalenie hierarchii pomiędzy nimi. Te dwie reguły priorytetu, to:

1. „Zasady sprawiedliwości mają być zestawione w porządku linearnym, a co za tym idzie - wolność może być ograniczona jedynie w imię wolności. Istnieją dwa przypadki:

a) mniejszy zakres wolności musi wzmacniać całościowy system wolności, która jest udziałem wszystkich;

b) wolność mniej niż równa musi być do przyjęcia dla tych, którzy mają mniej wolności.

2. Druga zasada sprawiedliwości ma w porządku linearnym pierwszeństwo wobec zasady efektywności i wobec zasady maksymalizowania sumy korzyści; zaś zasada równych szans ma pierwszeństwo wobec zasady dyferencji. Istnieją dwa przypadki:

a) nierówność szans musi zwiększać szanse tych, którzy maja mniejsze szanse;

b) nadmierna stopa oszczędzania musi per saldo zmniejszyć ciężary tych, którzy to obciążenie biora na siebie"".

Teoria sprawiedliwości ma charakter deontologiczny. Opozycja między deontologicznością a teleologicznością koncepcji sprawiedliwości zbudowana jest w oparciu o wizję roli dobra w identyfikacji tego, co słuszne. Teorie teleologiczne nadawały słuszności rolę służebną w stosunku do dobra. Celem samym w sobie jest zawsze dobro, zaś słuszność ma wartość jedynie instrumentalną w stosunku do niego. Rawls definiuje swoja koncepcję sprawiedliwości jako bezstronności tak, aby owa bezstronność oznaczała wyraźne oddzielenie dobra od słuszności. Osią rozumowania Rawlsa nie jest więc dobro, lecz wywiedziona niezależnie od niego sprawiedliwość ${ }^{10}$. Deontologiczny charakter teorii sprawiedliwości jest zresztą jednym z przedmiotów polemiki komunitarystów z liberałami, o czym poniżej.

Nie należy postrzegać sporu będącego przedmiotem tej pracy jako „sporu między protagonistami indywidualnej wolności a tymi,

\footnotetext{
8 Tamże, s. 414-415.

9 Tamże, s. 415-416.

${ }^{10}$ R. Prostak, dz. cyt., s. 64 i nast.
} 
którzy sądzą, że wartości kultywowane we wspólnocie bądź wola większości powinny zawsze nad nią przeważać, lub też między wyznawcami uniwersalnych praw człowieka a tymi, którzy obstaja przy twierdzeniu, że nie istnieje możliwość krytyki czy osądu wartości, które ożywiają inne kultury i tradycje" ${ }^{11}$. Ma on charakter dalece bardziej doniosły filozoficznie oraz zniuansowany, niż to się przyjmuje w jego pobieżnych, wskazanych powyżej, interpretacjach i dlatego wymaga dokładnego rozpatrzenia.

Spór liberałów z komunitarystami, jako wielowątkowy wymaga pewnej systematyzacji. Krytyka komunitarystyczna organizuje się na trzech poziomach refleksji:

1. metateoretycznym - dotyczącym kwestii neutralności oraz usytuowania kulturowego i ich związku z prawomocnością wnioskowań i twierdzeń ontologicznych, moralnych oraz politycznych;

2. ontologicznym (w sensie ontologii społecznej) - dotyczącym (społecznej) natury jaźni oraz

3. praktycznym (przez analogię do przedmiotu badań filozofii praktycznej) - dotyczącego dobrego społeczeństwa i związku politycznego $^{12}$.

Poziom metateoretyczny faktycznie odnosi się do sporu na płaszczyznach uniwersalizm - partykularyzm i subiektywizm obiektywizm. Komunitaryści zarzucają Rawslowi, że prezentuje on swoją teorię jako uniwersalną prawdę, co samo w sobie zamyka drogę tak do jej krytyki, jak i do przedstawienia dla niej jakiejkolwiek alternatywy. Rawls stwierdza bowiem, iż „sprawiedliwość jako bezstronność (...) ustanawia pewien archimedesowy punkt dla oceny systemu społecznego, bez odwoływania się do jakiś okoliczności apriorycznych" "13. Zasady teorii liberalnej miałyby być stosowalne w każdym społeczeństwie, o którym można pomyśleć, jednak jak wskazują Michael Walzer i Charles Taylor, w ten sposób liberalizm ignoruje jakikolwiek partykularyzm kulturowy. Rawls uznaje, iż jednostki znajdujące się za zasłoną niewiedzy nie kierują się żadną partykularną wizja dobra, dostępne są im bowiem tylko informacje o dobru wąskim. Jednak i samo dobro wąskie również nie odpowiada wymogom uniwersalizmu. Wartości wchodzące w jego skład

\footnotetext{
${ }_{11}$ M. Sandel, Liberalism and the Limits of Justice, New York 1997, s. 9-10.

12 Por. L. Dominiak, Nowoczesna wspólnota, çylli liberatowie versus komunitaryśsi, „Edukacja Filozoficzna”, 2003, nr 36, s. 245-251; tenże, Communitarianism as a Refutation of Liberalism, „Polish Political Science Yearbook”, 2005, s. 190-193; tenże, Komunitaryzm, dz. cyt., s. 187-190.

13 J. Rawls, dz. cyt., s. 360.
} 
także są kulturowo uwarunkowane i nie są tożsame w każdej społeczności, nie da się ich stosować do grup czy społeczeństw preferujących na przykład wartości kolektywne ${ }^{14}$. Nawet dobro wąskie musi być umocowane we wspólnocie i przez nią identyfikowane, a to podważa samą istotę teorii liberalnej. Jeśli bowiem udaje się obalić uniwersalizm dobra wąskiego, to, sądzi Walzer, należy ekstrapolować ten wniosek także na koncepcje sprawiedliwości w ogóle ${ }^{15}$. Liberalizm, jak wskazuja komunitaryści, głosi swoją prymarność wobec każdej koncepcji dobra, sam zaś rzekomo nie narzuca apriorycznego sposobu na życie określane jako dobre. Stąd też liberalizm (według liberałów) nie jest żadną partykularną koncepcją dobra ani takowej nie proponuje, ma więc wymiar ponadkulturowy. Komunitaryści ripostuja, iż teoria liberalna jest skażona w równym stopniu jak każda inna przez preferencje filozoficzne, że rości sobie prawo do usytuowania liberalizmu poza lub ponad kultura, jakakkolwiek wizją dobra i resztą światopoglądów, podczas gdy jest on tylko jednym z wielu - walczącym wyznaniem (a fighting creed) ${ }^{16}$. Liberalizm więc pomimo tego, że sam jest zakorzeniony w kulturze przypisuje sobie pozycję ponad nią. Zdaniem MacIntyre'a taka teoria jest po prostu niemożliwa: „Nie ma żadnego innego punktu oparcia, miejsca poznawczego, nie można inaczej angażować się w rozwijanie, ocenę, akceptację i odrzucanie racjonalnego argumentu, jak tylko taki, który wynika $z$ tej lub innej tradycji”, ${ }^{17}$.

W wymiarze metateoretycznym komunitarystyczna krytyka liberalnej teorii odnosi się także do jej deontologicznego charakteru. Zarzuty komunitarystyczne dotyczą w tej materii dwóch kwestii: budowy dobrego społeczeństwa bez odwoływania się do koncepcji dobra, ale także wskazują na zagrożenia dla tego społeczeństwa ze strony samych koncepcji deontologicznych. Najpoważniejsze bodaj zarzuty deontologicznemu charakterowi teorii Rawlsa stawia Sandel. Wskazuje on na pozorność zabiegu Rawlsa z oddzieleniem dwóch teorii dóbr. Twierdzi on, że zasady sprawiedliwości zostają ustalone tylko w oparciu o dobra minimalne, jednak, zdaniem Sandela, te dobra (co zostało już wspomniane przy okazji Walzera krytyki uniwersalizmu teorii liberalnej) wywiedzione są z konkretnej kultury - zachodniej. Nie można w ogóle utrzymać wizji społeczeństwa opartego na koncepcji dobra, które nie jest zakorzenione we wspólnocie i nie jest w niej identyfikowane jako służące jej członkom. Podobny zarzut stawia Rawlsowi Taylor, wskazując, iż

\footnotetext{
14 A. Szahaj, E pluribus unum?, Kraków 2004, s. 26.

15 M. Walzer, Spheres of Justice, New York 1983, s. 79.

${ }^{16}$ Ch. Taylor, Philosophical Arguments, Cambridge 1995, s. 249.

17 A. MacIntyre, Whose Justice? Which Rationality?, London 1988, s. 350.
} 
zasady sprawiedliwości opierają się przecież na dobru wąskim, ale jednak na dobru. Tym samym zasady te nie zostają wywiedzione niezależnie od jakiejkolwiek wizji dobra, lecz explicite opieraja się na niej ${ }^{18}$.

$\mathrm{Na}$ koniec należy wskazać na jeszcze jedną uwagę natury metateoretycznej, która odnosi się do koncepcji liberalnej. Nawet odejście od wszelkich koncepcji dobra jest pewną koncepcją dobra uznania społeczeństwa, które nie jest ufundowane na żadnej partykularnej wizji dobra za najbardziej pożądane, czyli w istocie za dobre.

Zdaniem komunitarystów, na poziomie ontologicznym liberalna teoria polityczna przyjmuje, iż ludzie są różni od wartości, które wyznaja, że są uprzedni wobec nich, że wybieraja je dowolnie. Według komunitaryzmu jest odwrotnie i to właśnie wartości konstytuuja jaźń. Człowiek nie istnieje poza społeczeństwem, nie istnieje poza wspólnota, która go tworzy ${ }^{19}$. Zdefiniowanie jednostki bez odwoływania się do tego, co społeczne nie jest możliwe, gdyż człowiek pozbawiony wartości, to człowiek, który nie ma żadnego punktu odniesienia. Do takiej wizji człowieka odnosi się MacIntyre pisząc o narracyjnej koncepcji jaźni. Jednostka potrzebuje ciagłej interakcji z innymi narracjami. „Jestem częścia historii życia innych ludzi, tak samo jak oni są częścią mojej historii" 20 . Biografie poszczególnych ludzi są osadzone tylko wewnątrz historii poszczególnych wspólnot, są ciagła interakcją $z$ innymi. Rozumowanie człowieka jest aktem społecznym, gdyż zachodzi tylko w społecznej przestrzeni. Inni są niezbędni do tego, by zrozumieć własne myśli czy działania, tak więc zrozumiałość jest wtórna w stosunku do relacji z innymi ${ }^{21}$. Jedność życia ludzkiego i jego racjonalizacja możliwa jest tylko dzięki wspólnocie i tylko wewnątrz niej, interpretacja każdego zachowania następuje tylko poprzez wspólnotę. Takie rozumowanie prowadzi zresztą MacIntyre'a do wniosku, iż jakiekolwiek pojęcie istoty zachowania możliwe jest tylko dla osób wtajemniczonych, dla tych, którzy zinternalizowali kontekst wspólnotowy.

$\mathrm{Na}$ nierozerwalność wartości, które wytwarzane są zawsze we wspólnocie, wskazuje też Sandel i proponuje ideę ,podmiotu radykalnie usytuowanego", który nie jest uprzedni wobec wartości, które wyznaje, lecz to one decyduja o tym, kim jest. Nie zgadza się tym samym z teoria, jak to określa, ,podmiotu wykorzenionego” lub ,suwerennego podmiotu wyboru” prezentowaną przez Rawlsa w Teorii sprawiedliwości, w której Ja

${ }^{18}$ Ch. Taylor, Źródta podmiotowości, Warszawa 2001, s. 176.

19 A. Szahaj, Jednostka czy wspólnota?, Warszawa 2000, s. 18.

20 A. MacIntyre, Driedzictwo cnoty, Warszawa 1996, s. 389.

21 A. Gawkowska, Biorqc wspólnote poważnie?, Warszawa 2004, s. 129. 
jest aprioryczne wobec swoich celów i wartości. Jak mówi: „Wedle koncepcji Rawlsa charakterystyki, które posiada Ja, nie są przypisane do jaźni, lecz tylko odniesione do niej, znajdują się zawsze w pewnym dystansie od niej. To jest to, co czyni je atrybutami raczej niż czynnikami konstytuującymi moją osobę: one są moje raczej, niż są mną, rzeczami, które mam raczej, niż którymi jestem" "22.

Również Taylor, odwołując się do antykantowskiej filozofii moralności Hegla i czerpiąc z niej dwie kluczowe kategorie - Moralität i Sittlichkeit, wskazuje na umocowanie jednostki w inny sposób, niż wynikałoby to z filozofii Rawlsa. Moralität jest efektem negacji prawa obiektywnego i potraktowania go raczej jako narzuconego i zupełnie zewnętrznego. Takie prawo nie może być zinternalizowane, a jego wymagania budzą w jednostce niezgodę. Z drugiej zaś strony stawia Hegel Sittlichkeit, moralność społeczna, która musi być zinternalizowana, gdyż jednostka przyjmuje ja jako swoją. Moralität może przerodzić się w złe sumienie, jednak nigdy nie stanie się tak ze (używając nomenklatury komunitarystycznej) wspólnotowo umocowanym Sittlichkeit. Taylor neguje liberalną istotę moralnych decyzji, które, zdaniem samych liberałów, wynikają tylko z kantowskiego imperatywu kategorycznego i dzięki heglowskiemu Sittlichkeit istotę wyborów moralnych umiejscawia raczej na łonie wspólnoty, gdyż moralność w tym rozumieniu poza wspólnotą w ogóle nie istnieje.

$\mathrm{Na}$ poziomie praktycznym komunitaryzm krytykuje negatywne aspekty życia w liberalnym społeczeństwie: egoistyczną rywalizację, zanik wartości moralnych, permisywizm, fakt istnienia grup społecznych, którym nie powiodło się na liberalnym rynku, a które sa poddane ekskluzji, upadek etosu służby i społeczeństwa obywatelskiego, szalejący konsumpcjonizm etc. ${ }^{23} \mathrm{Wg}$ komunitarystów społeczeństwo liberalne lansuje aspołeczny indywidualizm ${ }^{24}$ i ulega zatomizowaniu ${ }^{25}$. W Komunitarystycznej Platformie Programowej, podpisanej przez m.in. B. Barbera, R. Bellaha, A. Etzioniego, F. Fukuyamę czy L. Thurowa, komunitaryzm prezentuje twierdzenie, iż ani ludzkie istnienie, ani wolność indywidualna nie są na dłuższą metę możliwe poza obrębem wspólnot. Te wspólnoty powinny być przede wszystkim responsywne, co oznacza, że pożądane jest, by były wrażliwe na potrzeby swych członków. Komunitaryści optują w tej Platformie za silną demokracją,

22 M. Sandel, dz. cyt., s. 85.

23 Por. L. Dominiak, Komunitaryzm, dz. cyt., s. 188-190.

24 A. MacIntyre, Driedzictwo cnoty, dz. cyt., s. 444.

${ }^{25}$ Ch. Taylor, Atomism, w: tenże, Philosophy and the Human Sciences. Philosophical Papers, Cambridge 1985, s. 187. 
większym wpływem obywateli na decyzje polityczne, ograniczeniem roli prywatnych pieniędzy i interesów w polityce, korupcji władz; sprzeciwiaja się lobbingowi, finansowaniu kampanii wyborczych przez osoby prywatne; proponuja płatne urlopy rodzicielskie oraz dodatkowe urlopy bezpłatne, elastyczne godziny pracy, dzielenie etatów, stwarzanie możliwości pracy w domu a wszystko w celu polepszenia warunków wychowywania dzieci. W tym celu też opowiadaja się za zaostrzeniem i zmiana, na bardziej prodziecięce, prawa rozwodowego. Chcą też większego poszanowania praw mniejszości. Nawołuja do pracy ochotniczej, pełnienia funkcji sędziów przysięgłych, płacenia podatków, opiekowania się starszymi i chorymi członkami wspólnot. Opowiadaja się również za prowadzeniem kontroli trzeźwości, instalowaniem na lotniskach bramek kontrolnych, poddawaniem ludzi, którzy maja bezpośredni wpływ na bezpieczeństwo publiczne, testom na używanie narkotyków i alkoholu ${ }^{26}$.

Reasumując, warto zauważyć, iż analiza sporu liberalizmu z komunitaryzmem pozwala jednoznacznie odrzucić pojawiające w sekundarnej literaturze przedmiotu insynuacje jakoby:

1. spór ten miał charakter jedynie lokalny w sensie czasowym i przestrzennym, czyli był ograniczony do realiów polityki i społeczeństwa Stanów Zjednoczonych przełomu wieków;

2. komunitaryzm był jedynie wewnętrzną korektą liberalizmu a nie odrębnym nurtem filozoficznym.

Odrzucając pierwszy rodzaj imputacji należy z cała stanowczościa podkreślić, iż z sygnalizowanych w tej pracy problemów istotowe dla sporu znaczenie maja aporie metateoretyczne i ontologiczne resp. antropologiczne, a tzw. poziom praktyczny ma znaczenie jedynie o tyle, o ile jest logiczna konsekwencją rozstrzygnięć na pozostałych poziomach refleksji. Jest zaś sprawą jasną dla każdego wiedzącego cokolwiek o filozofii, iż problemy metateoretyczne i ontologiczne maja charakter uniwersalny. Stąd też taki sam charakter posiada spór liberałów z komunitarystami.

Refutując drugą obiekcję można po pierwsze zrekapitulować zasadnicze punkty niezgody przytoczone w tej pracy, ale również odnieść się do innych - tym razem wymierzonych wprost w ten zarzut argumentów. Inter alia warto wskazać tu antymodernistyczny charakter komunitaryzmu, zwłaszcza w jego odsłonie MacIntyre’a, który jest

${ }^{26}$ Komunitariańska Platforma Programowa. Spoteczeństwo responsywne: prawa i obowiazki, w: Komunitarianie. Wybór tekstów, pod red. Pawła Śpiewaka, Warszawa 2004, s. 17-34. 
opozycyjny do oświeceniowego i modernistycznego liberalizmu ${ }^{27}$ lub komunitarystyczny antyindywidualizm (występujący zwłaszcza u Sandela, MacIntyre'a i Taylora) i antykontraktualizm.

Komunitaryzm, mimo swego eklektyzmu i heterogeniczności, jawi się więc jako samodzielny nurt filozoficzny, co staje się jeszcze bardziej widoczne, gdy zważy się na kontekst jego wyłonienia się. Przełom lat 70. i 80., to czas zaprzeczenia defetystycznej tezie Lasletta, Voegelina i Straussa o końcu filozofii polityki. Paradoks dziejów polega bowiem na tym, iż wygłoszenie tej diagnozy-proroctwa spowodowało jej sukcesywną autonegację, która dokonała się ostatecznie w ostatnich trzech dekadach ubiegłego wieku. Dokonała się właśnie za sprawą sporu liberałów z komunitarystami.

27 Zob. L. Morawski, Gtówne problemy wspótczesnej filozofii prawa, Warszawa 2003, s. 46-75 i 166-167. 